\title{
Coping with food and nutrition insecurity in Zimbabwe: does household head gender matter?
}

Terrence Kairiza ${ }^{1 *}$ and George D. Kembo ${ }^{2}$

\author{
* Correspondence: tkairiza@yahoo. \\ com \\ ${ }^{1}$ Department of Economics, Bindura \\ University of Science Education, P. \\ Bag, 1020 Bindura, Zimbabwe \\ Full list of author information is \\ available at the end of the article
}

\begin{abstract}
On the basis of a large-scale nationally representative sample of household data from five pooled cross-section surveys conducted by the Zimbabwe Vulnerability Assessment Committee (ZimVAC), this study assesses the existence of gender differences in the vulnerability to food and nutrition insecurity, usage of consumption-based and livelihoods-based coping strategies, and the existence of gender heterogeneity in the correlation of usage of such coping strategies when confronted by food and nutrition insecurity. The study offers three main findings. Firstly, female-headed households are more susceptible to food and nutrition insecurity than those headed by males. Secondly, female-headed households are more likely to employ consumption-based coping strategies than their male counterparts, but there is no statistically significant difference in the usage of livelihoods-based coping strategies. Finally, whilst there is little evidence of gender heterogeneity in the correlation of the usage consumption-based coping strategies, there is overwhelming evidence that female-headed household heads are less likely to adopt livelihoods-based coping strategies when confronted with food and nutrition insecurity. The sum total of these findings is that whilst female-headed households are more prone to food insecurity than their male counterparts, they are less able to use livelihoods-based coping strategies to weather household food and nutrition insecurity than their male counterparts.

Keywords: Gender differences, Food security

JEL classification: J16, Q18
\end{abstract}

\section{Introduction}

Idiosyncratic and systemic shocks such as climate change (FAO 2010; Tirado et al. 2010), food price hikes (Christian 2010; FAO 2008; Quisumbing, et al. 2008), or global economic crises (Ivanic and Will 2008; Ivanic et al. 2012) impose gender-heterogenic consequences on food and nutrition security of households (Klasen et al. 2015). Vis-àvis male-headed households, female-headed households have different demographic and socio-economic conditions, resource utilization patterns, and social network patterns (Croson and Gneezy 2009; Fletschner and Carter 2008; Fletschner et al. 2010; Gneezy and Rustichini 2004; Kairiza et al. 2017; Powell and Ansic 1997; Reevy and Maslach 2001) which renders them more susceptible to food and nutrition insecurity than their male counterparts (Horrell and Krishnan 2007; King-Dejardin and Owens

(C) The Author(s). 2019 Open Access This article is distributed under the terms of the Creative Commons Attribution 4.0 International License (http://creativecommons.org/licenses/by/4.0/), which permits unrestricted use, distribution, and reproduction in any medium, provided you give appropriate credit to the original author(s) and the source, provide a link to the Creative Commons license, and indicate if changes were made. 
2009; Klasen et al. 2015; Peterman et al. 2010; Quisumbing 1996; Quisumbing and McClafferty 2006; Quisumbing and Pandolfelli 2009). Concomitant to the aforementioned gender heterogeneity in vulnerability to food and nutrition insecurity, are gender differences in the strategies employed by households to subsist when confronted with food and nutrition insecurity which are termed consumption-based and livelihoodsbased coping strategies (Dercon and Krishnan 1999; Fafchamps et al. 1998; Gupta et al. 2015).

This study expands on the body of literature focusing on gender and food and nutrition insecurity on the basis of a pool of five nationally representative cross-section surveys, comprising both rural and urban households in Zimbabwe. The annual household surveys employed in this study span from 2013 to 2017 and were conducted by the Zimbabwe Vulnerability Assessment Committee (ZimVAC). Specifically, on the basis of the gender of the household head, this study appraises the existence of the gender gap in food and nutrition insecurity in Zimbabwe. Secondly, it assesses the existence of gender differentials in the usage of consumption-based and livelihoods-based coping strategies in Zimbabwe. Finally, it evaluates gender heterogeneity in the correlation of the household usage of coping strategies when confronted with food and nutrition insecurity. The study measures food and nutrition insecurity on the basis of five proxies which are the household hunger score, poor food consumption score, and household consumption of vitamins, proteins, and iron.

The study offers three major findings. Firstly, female-headed households in Zimbabwe are more prone to food and nutrition insecurity after controlling for major confounding variables. Secondly, in light of the high vulnerability to food and nutrition insecurity, vis-à-vis male-headed households, female-headed households are more likely to use consumption-based coping strategies, but not livelihoods-based coping strategies. Finally, in terms of gender heterogeneity in the correlation of household usage of coping strategies when confronted with food and nutrition insecurity, female-headed households are less likely to employ livelihoods-based coping strategies but not in respect of consumption-based coping strategies than their male counterparts.

The next section of this paper reviews the relevant literature and outlines hypotheses to be examined in this study. The 'Methods' section details the methods employed in the study, whilst the 'Discussion' section provides a discussion of the results. Finally, the 'Conclusion and policy recommendations' section concludes.

\section{Literature review and hypotheses}

In comparison to their male counterparts, female household heads and women, in general, have different observable and unobservable demographic and socio-economic conditions (Croson and Gneezy 2009; Fletschner and Carter 2008; Fletschner et al. 2010; Gneezy and Rustichini 2004; Kairiza et al. 2017; Powell and Ansic 1997; Reevy and Maslach 2001). Concomitant to differences in observable and unobservable demographic and socio-economic conditions are gender differences in agricultural productivity and food and nutrition insecurity vulnerability (Horrell and Krishnan 2007; KingDejardin and Owens 2009; Klasen et al. 2015; Peterman et al. 2010; Quisumbing 1996; Quisumbing and McClafferty 2006; Quisumbing and Pandolfelli 2009). The reports by FAO $(2010,2011)$ note that women and girls are overrepresented amongst the population of people who food and nutrition insecure worldwide. In this background, the 
following hypothesis linking the food and nutrition insecurity status of the household and the gender of the household head is proposed:

\section{Hypothesis 1}

Female-headed households are more likely to be food and nutrition insecure than male-headed households.

When confronted by food and nutrition insecurity, households employ strategies to weather the insecurity (Dercon and Krishnan 1999; Fafchamps et al. 1998; Gupta et al. 2015). There are two types of strategies engaged by households to cope with food insecurity which are consumption-based and livelihoods-based coping strategies. Consumption-based coping strategies involve short-term adjustments of food consumption patterns, whereas livelihoods-based coping strategies involve long-term adjustments of income earning or food production patterns, as well one-off responses such as sale of durable assets (Christiaensen and Boisvert 2000; Coates et al. 2006; Maxwell and Caldwell 2008; Maxwell et al. 1999).

The role of food preparation and distribution is largely carried out by women in Zimbabwe. In light of food and nutrition insecurity, it is therefore easier for women and female household heads to engage in short-term adjustments of consumption patterns such as controlling the food portion size and food rationing or consumption of less preferred foods (Günther and Harttgen 2009; Skoufias and Quisumbing 2005). In view of the mentioned higher propensity to use short-term consumption-based coping strategies, the following hypothesis connecting the gender of the household head and the adoption of consumption-based coping strategies is suggested.

\section{Hypothesis 2.1}

Female-headed households are more likely to employ consumption-based coping strategies than male-headed households.

Extant studies note that men are more able to employ livelihoods-based coping strategies than women (Günther and Harttgen 2009; Skoufias and Quisumbing 2005). Men are more concerned with long-term livelihood security and, to this end, tend to control market-based coping such as the sale of assets or labour and loan arrangements with patrons and moneylenders. They also negotiate inter-household exchanges involving more substantial transfers of food, labour, or cash (Günther and Harttgen 2009; Skoufias and Quisumbing 2005). In that matrix, notwithstanding their higher likelihood to face food and nutrition insecurity, female household heads are more likely to be constrained by unobserved societal and cultural restrictions as well as prior endowments in income and capital which limits their ability to employ livelihoods-based coping strategies. The following hypothesis linking the adoption of livelihoods-based coping strategies and the gender of the household head is therefore proposed.

\section{Hypothesis 2.2}

Female-headed households are no more likely to employ livelihoods-based coping strategies than male-headed households. 
The aforementioned household head gender differentiation in the ability to implement consumption-based coping strategies and livelihoods-based coping strategies is likely to result in gender heterogeneity in the correlation of household usage of coping strategies and the incidence of food and nutrition insecurity. Notwithstanding, the fact that female household heads are hypothesized to employ more consumption-based coping strategies than their male counterparts, there is likely to be a female who is responsible for those activities in male-headed households to the extent that there is not so much gender heterogeneity in the usage of such consumption-based coping strategies in households headed by females and those headed by males. In light of this, the following hypothesis linking the gender of the household head and the usage of consumption-based coping strategies when confronted by food and food and nutrition insecurity is proposed.

\section{Hypothesis 3.1}

There is no gender difference in the likelihood the household implementation of consumption-based coping strategies when confronted with food and nutrition insecurity.

The usage of livelihoods-based coping strategies when confronted with food and nutrition insecurity is likely to be influenced by the ease with which one can implement the livelihoods-based coping strategies. As already noted, female household heads are likely to be more constrained in their usage of livelihoods-based coping strategies than their male counterparts. In this background, the following hypothesis linking the usage of livelihoods-based coping strategies when confronted by food and nutrition insecurity and the gender of the household head is suggested.

\section{Hypothesis 3.2}

Female-headed households are less likely to implement livelihoods-based coping strategies when confronted by food and nutrition insecurity than their male counterparts

\section{Methods}

Data

This paper employs nationally representative household data on rural and urban livelihoods from five annual pooled cross-section surveys conducted by the Zimbabwe Vulnerability Assessment Committee (ZimVAC) which is a consortium comprising of the Zimbabwean government, UN agencies, and non-governmental organizations. The household assessment surveys span from 2013 to 2017 totaling 67,857 households as

Table 1 Distribution of observations by year

\begin{tabular}{llll}
\hline & Female $[F]$ & Male $[M]$ & Total $[F+M]$ \\
\hline 2013 & 3664 & 7034 & 10,698 \\
2014 & 3788 & 6910 & 10,698 \\
2015 & 3787 & 6866 & 10,653 \\
2016 & 7622 & 16,355 & 23,977 \\
2017 & 4221 & 7610 & 11,831 \\
Total & 23,082 & 44,775 & 67,857 \\
\hline
\end{tabular}

Notes: The 2016 survey also includes both urban and rural households with 14,434 and 9,543 observations, respectively 
shown in Table 1. Save for the 2016 data which comprises both rural and urban households, the surveys focused on rural households. Table 1 shows that the 2013 and 2014 surveys covered 10,698 observations each, whereas the 2015, 2016, and 2017 surveys had 10,653, 23,977, and 11,831 observations, respectively. In terms of the gender distribution of the household heads, there are a total of 23,082 female-headed and 44,775 male-headed households.

\section{Measurement of key variables}

\section{Food and nutrition insecurity}

This study uses five proxies to measure the food and nutrition insecurity status of the household. Firstly, the study uses the Household Hunger Score (HHS). The household hunger score is a weighted index created from the summation of the questions to which the household responds affirmatively to questions of having experienced a day with no food of any kind in the household, went to sleep at night hungry because there was no food, or go a whole day and night without anything to eat at all because there was not enough food to eat in the household. This therefore implies that for household $i$ :

$\mathrm{HHS}_{i}=\#\{$ Questions answered affirmatively by household $i\}$

$\mathrm{HHS}_{i}$ takes values from 0 , up to and including 3 . The higher the household hunger score, the more food and nutrition insecure the household is.

The second measure is the poor food consumption score. The household food consumption score is a measure of dietary diversity, food frequency, and the relative nutritional importance of the food consumed. A high food consumption score increases the possibility that a household achieves nutrient adequacy. The food consumption score is used to classify households into three groups: poor, borderline, or acceptable food consumption. One is taken to haven to have a poor food consumption score if that household has a food consumption score that is less than 21. The poor food consumption score variable therefore takes the value of one if the household food consumption score is less than 21 and 0 otherwise.

The final three measures take the value of 1 if the household has not consumed foods that contain minerals, proteins, or iron. If the household has not consumed minerals, vitamins, or iron, the household is taken to be food and nutrition insecure.

\section{Measures of consumption and livelihoods based coping strategies}

The CSI of a household is calculated by multiplying the frequency of consumption coping strategies used in the last 30 days with their respective severity weights. The coping strategies and their weights are shown Table 8 in Appendix 1 of this study. Similarly, the livelihoods-based coping strategies index is acquired by multiplying the use of the livelihoods strategies by their severity weights as shown Table 9 in Appendix 2 of this study.

\section{Statistical estimation}

To understand the impact of gender on, the household propensity to be food and nutrition insecure as stipulated in Hypothesis 1, the adoption of consumption-based coping strategies as stipulated in Hypothesis 2.1, or the adoption of livelihoods-based coping 
strategies, as stipulated in Hypothesis 2.2, the following OLS regression model is proposed:

$$
\mathrm{Y}_{\mathrm{i}}=\alpha+\gamma \mathbf{X}_{\mathrm{i}}+\varepsilon_{\mathrm{i}}
$$

$Y_{i}$ takes the value of the household food and nutrition insecurity status or the level of adoption of consumption-based or livelihoods-based coping strategies. As previously noted, the household food and nutrition insecurity status is proxied by five measures which are the household hunger scale, poor food consumption score, never consuming vitamins, never consuming minerals, or never consuming iron. The higher the value of the food and nutrition insecurity proxies, the higher the food and nutrition insecurity of the household. $\mathbf{X}_{\mathrm{i}}$ is a vector of the background characteristics of the household head, the household characteristics, provincial dummies, as well as year dummies since the data used was collected in five annual surveys. $\mathbf{X}_{\mathrm{i}}$ also captures the gender of the household head. The gender variable takes the value of 1 if the household head is female and 0 otherwise. The study is interested in the coefficient of the gender variable as an answer to Hypotheses 1, 2.1 and 2.2 of this study. Results of the OLS estimation of Eq. (1) are presented in Tables 5 and 6 of this study.

Hypotheses 3.1 and 3.2 pays heed to the gender heterogeneity in the usage of consumption-based coping strategies and livelihoods-based coping strategies when confronted by food and nutrition insecurity. To capture the gender heterogeneity, the following regression model is proposed:

$$
\mathrm{Y}_{\mathrm{i}}=\alpha+\beta \text { Coping }_{\mathrm{i}} \times \text { Gender }+\rho \text { Gender }_{\mathrm{i}}+\phi \text { Coping }_{\mathrm{i}}+\gamma \mathbf{X}_{\mathrm{i}}+\varepsilon_{\mathrm{i}}
$$

In the case of Eq. (2), $Y_{i}$ is the household food and nutrition insecurity status. The variable Coping represents consumption-based or livelihoods-based coping strategies, whereas the variable Gender represents the gender of the household head which takes the value of 1 if the household is female and 0 otherwise. The results of the OLS regression estimation of Eq. (2) are presented in Table 7 of this study.

\section{Discussion}

\section{Descriptive analysis}

\section{Background characteristics of the household heads}

Table 2 shows the background characteristics of the household heads by the gender of the household head. According to the table, female household heads tend to be older than the male household heads by 4.4 years. The age difference is statistically significant at the $1 \%$ level of significance. Table 2 also reveals that of the female household heads, only $18.5 \%$ reported that they were married and living together with their spouse. This number is a far cry from the male household heads who reported that 89.7\% of them were married and living together with their spouse. The difference in the proportion of female and male household heads who were married and living together with their spouse is $71.2 \%$ and it is statistically significant at the $1 \%$ level of significance. The large gender difference in the marital status of the household heads is however not surprising given the cultural and societal setting of Zimbabwe which preserves the household head status for the husband in the marriage setting. The female heads of the household heads are more likely to found in settings where they are widowed (51.8\%), married but living apart (14.2\%), or divorced or separated (11.9\%). 
Table 2 Background characteristics of the household heads by gender

\begin{tabular}{llll}
\hline Variable & Female $[F]$ & Male $[M]$ & Difference $[F-M]$ \\
\hline Age [Years] & 51.078 & 46.725 & $4.353^{* * *}$ \\
Marital status & & & \\
$\quad$ Married living together & 0.185 & 0.897 & $-0.712^{* * *}$ \\
Married living apart & 0.142 & 0.035 & $0.107^{* * *}$ \\
Divorced/separated & 0.119 & 0.014 & $0.105^{* * *}$ \\
Widowed/widower & 0.518 & 0.030 & $0.488^{* * *}$ \\
Never married & 0.035 & 0.023 & $0.012^{* * *}$ \\
Level of education & & & \\
No education & 0.197 & 0.093 & $0.104^{* * *}$ \\
Primary level & 0.369 & 0.274 & $0.095^{* * *}$ \\
ZJC & 0.193 & 0.200 & $-0.007^{* *}$ \\
O' level & 0.173 & 0.289 & $-0.116^{* * *}$ \\
A' level & 0.049 & 0.101 & $-0.053^{* * *}$ \\
Diploma/certificate after primary & 0.005 & 0.011 & $-0.005^{* * *}$ \\
Diploma/certificate after secondary & 0.011 & 0.023 & $-0.012^{* * *}$ \\
Graduate/post-graduate & 0.003 & 0.009 & $-0.006^{* * *}$ \\
\hline
\end{tabular}

Notes: The fourth column shows the results of two-tailed $t$-test for the difference in the means

$*^{* *}, * *$, and ${ }^{*}$ indicate the 1,5 , and $10 \%$ levels of significance

The respective proportions for these marital statuses for male household heads are 3\%, $3.5 \%$, and $1.4 \%$.

In terms of the average level of education, Table 2 reveals that the proportion of female household heads that had no education is $19.7 \%$ versus the $9.3 \%$ for male household heads. Furthermore, only $17.3 \%$ of the female household heads had completed O' level education versus $28.9 \%$ of the male household heads.

The major take is that female household heads are older, more likely to be found in settings where they do not have a spouse and are less educated than their male counterparts. This finding is consistent with the earlier findings that find that female household heads have different observable and unobservable background characteristics from their male counterparts (Croson and Gneezy 2009; Fletschner and Carter 2008; Fletschner et al. 2010; Gneezy and Rustichini 2004; Kairiza et al. 2017; Powell and Ansic 1997; Reevy and Maslach 2001).

\section{Gender differences in the characteristics of households}

Table 3 shows the gender heterogeneity in the characteristics of the households headed by females and males, respectively. According to Table 3, female-headed households tend to be statistically smaller than those headed by males. The households headed by females average 4.83 members whereas those headed by males tend to average 5.3 members. The difference of 0.47 members is statistically significant at the $1 \%$ level of significance. Ceteris paribus, the observed gender difference in household size, is logical given that the majority of female household heads tend to be widowed as Table 2 previously intimated. Unlike male-headed households, the majority of the female-headed households are short of one member who constitutes the spouse of the household head.

Table 3 also reveals that female-headed households tend to have smaller average monthly income versus those headed by their male counterparts. Female-headed 
Table 3 Background of households

\begin{tabular}{llll}
\hline Variable & Female $[F]$ & Male $[M]$ & Difference $[F-M]$ \\
\hline Household size & 4.828 & 5.295 & $-0.467^{* * *}$ \\
Proportion of female members to household size & 0.606 & 0.467 & $0.139^{* * *}$ \\
Number of mentally ill household members & 0.089 & 0.085 & 0.004 \\
Number of chronically ill household members & 0.077 & 0.074 & 0.003 \\
Household income [USD] & 128.521 & 190.687 & $-62.167^{* * *}$ \\
Province & & & \\
Bulawayo & 0.011 & 0.010 & 0.001 \\
Manicaland & 0.131 & 0.101 & $0.030^{* * *}$ \\
Mashonaland Central & 0.093 & 0.140 & $-0.047^{* * *}$ \\
Mashonaland East & 0.141 & 0.143 & -0.002 \\
Mashonaland West & 0.095 & 0.139 & $-0.044^{* * *}$ \\
Matabeleland North & 0.114 & 0.109 & $0.005^{* *}$ \\
Matabeleland South & 0.139 & 0.095 & $0.044^{* * *}$ \\
Midlands & 0.127 & 0.140 & $-0.013^{* * *}$ \\
Masvingo & 0.125 & 0.103 & $0.022^{* * *}$ \\
Harare & 0.023 & 0.019 & $0.004^{* * *}$ \\
The household is located in rural areas [1 if yes] & 0.867 & 0.855 & $0.012^{* * *}$ \\
\hline
\end{tabular}

Notes: The fifth column shows the results of two-tailed $t$ test for the difference in the means

$* * * * *$, and ${ }^{*}$ indicate the 1,5 , and $10 \%$ levels of significance

households had on average a monthly income of USD128.52 versus USD190.69 for the male-headed households. Furthermore, female-headed households are more likely to be located in rural areas by a proportion of $1.2 \%$ than their male counterparts.

The findings presented in Table 3 further corroborate the findings in Table 2 and reaffirms the notion that female households have different socio-economic characteristics from those of male households (Croson and Gneezy 2009; Fletschner and Carter 2008; Fletschner et al. 2010; Gneezy and Rustichini 2004; Kairiza et al. 2017; Powell and Ansic 1997; Reevy and Maslach 2001). The differences in the socio-economic characteristics are likely to give rise to gender differences in the household propensity to food and nutrition insecurity and the coping strategies employed by the household when they are not controlled for.

\section{Gender differences in food insecurity and coping strategies}

Table 4 displays the gender differences in food and nutrition insecurity and the coping strategies indices of the households in Zimbabwe. Consistent with prior studies such Horrell and Krishnan (2007), King-Dejardin and Owens (2009), Klasen et al. (2015), Peterman et al. (2010), Quisumbing (1996), and Quisumbing and McClafferty (2006) amongst others, this study finds that female-headed households are more likely to be food insecure than their male counterparts. Table 4 shows that female-headed households have higher household hunger scores than their male counterparts. Femaleheaded households have average household hunger score of 0.53 versus the average household hunger score of male-headed of 0.47 . Furthermore, female-headed households have higher probability of never consuming foods with minerals, proteins or iron with the respective difference in proportions vis-à-vis male-headed households being 
Table 4 Food security by gender of the household head

\begin{tabular}{llll}
\hline Variable & Female $[F]$ & Male $[M]$ & Difference $[F-M]$ \\
\hline Hunger score & 0.525 & 0.474 & $0.051^{* * *}$ \\
Poor food consumption score & 0.202 & 0.169 & $0.033^{* * *}$ \\
Never consumes minerals & 0.357 & 0.343 & $0.015^{* * *}$ \\
Never consumes proteins & 0.198 & 0.154 & $0.044^{* * *}$ \\
Never consumes iron & 0.445 & 0.376 & $0.068^{* * *}$ \\
Consumption coping strategy index & 22.066 & 20.558 & $1.508^{* * *}$ \\
Livelihoods coping strategy index & 0.521 & 0.578 & $-0.057^{* * *}$ \\
\hline
\end{tabular}

Notes: The fourth column shows the results of two-tailed $t$-test for the difference in the means

$* * * * *$, and $*$ indicate the 1,5 , and $10 \%$ levels of significance

$0.02,0.04$, and 0.07 . These differences are all statistically valid at the $1 \%$ level of significance.

Table 4 also shows the differences in consumption and livelihoods-based coping strategies indices. Consistent with studies such as Cappellini et al. (2014), Günther and Harttgen (2009), and Skoufias and Quisumbing (2005), amongst others, Table 4 displays that female-headed households are more likely to employ consumption-based coping strategies than male-headed households before controlling for background characteristics. Female-headed households have higher consumption-based coping strategies index of 22.07 versus 20.56 for males. The difference of 1.51 is statistically significant at the $1 \%$ level of significance. This finding confirms that females as the preparers of food in the households are more able to reorganize consumption patterns in the household when faced with food insecurity.

Table 4 also shows that when one considers the livelihoods-based coping strategies female-headed households are less likely to employ livelihoods-based coping strategies than their male counterparts before controlling for background characteristics. Indeed, female-headed households have a livelihoods-based coping strategy index of 0.52 versus the 0.58 for male-headed households, giving rise to a difference of 0.06 which is statistically significant at the $1 \%$ level of significance. This table confirms the earlier findings of Günther and Harttgen (2009) and Skoufias and Quisumbing (2005), amongst others, who show that female-headed households are more restricted in the usage of livelihoods-based coping strategies than their male counterparts. Female household heads are less likely to be able to employ livelihoods-based coping strategies such as selling a house when confronted by food and nutrition insecurity than their male counterparts.

\section{Regression results}

The impact of gender impact on food and nutrition insecurity

Table 5 shows the impact of gender on food insecurity. According to column II of the table, if the household head is female, the probability of having a poor food consumption score increases by $1.56 \%$. Furthermore, columns IV and V of Table 5 shows that the probabilities of never consuming proteins or iron increases by $2.13 \%$ and $2.84 \%$, respectively. The findings presented in Table 5 confirm Hypothesis 1 of this study that female-headed households are more prone to food insecurity than their male counterparts even after controlling for the demographic characteristics of the households. The 
Table $\mathbf{5}$ OLS estimates of the impact of gender on food security

\begin{tabular}{|c|c|c|c|c|c|}
\hline \multirow[t]{2}{*}{ Variables } & $\begin{array}{l}\text { Hunger } \\
\text { score }\end{array}$ & $\begin{array}{l}\text { Poor food } \\
\text { consumption } \\
\text { score }\end{array}$ & $\begin{array}{l}\text { Never } \\
\text { consumes } \\
\text { minerals }\end{array}$ & $\begin{array}{l}\text { Never } \\
\text { consumes } \\
\text { proteins }\end{array}$ & $\begin{array}{l}\text { Never } \\
\text { consumes } \\
\text { iron }\end{array}$ \\
\hline & (I) & (II) & $(\mathrm{IV})$ & $(V)$ & (IV) \\
\hline \multirow[t]{2}{*}{ Household head is female } & -0.00889 & $0.0156^{* * *}$ & -0.00518 & $0.0213^{* * *}$ & $0.0284^{* * *}$ \\
\hline & $(0.0115)$ & $(0.00477)$ & $(0.00476)$ & $(0.00467)$ & $(0.00584)$ \\
\hline \multirow[t]{2}{*}{$\begin{array}{l}\text { Age of household head } \\
\text { [years] }\end{array}$} & $-\overline{0.00381 * * *}$ & $-0.00166^{* * *}$ & $-0.000820^{* * *}$ & $-0.000980^{* * *}$ & $-\overline{0.000810^{* * *}}$ \\
\hline & $(0.000267)$ & $(0.000111)$ & $(0.000108)$ & $(0.000109)$ & $(0.000135)$ \\
\hline \multirow[t]{2}{*}{ Married living together } & -0.0197 & $0.0173^{*}$ & -0.0122 & 0.00916 & -0.000982 \\
\hline & $(0.0233)$ & $(0.00885)$ & $(0.00905)$ & $(0.00868)$ & $(0.0112)$ \\
\hline \multirow[t]{2}{*}{ Married living apart } & $-0.0982^{* * *}$ & -0.0103 & -0.0103 & -0.00985 & $-0.0250^{* *}$ \\
\hline & $(0.0255)$ & $(0.00994)$ & $(0.0103)$ & $(0.00979)$ & $(0.0126)$ \\
\hline \multirow[t]{2}{*}{ Divorced/separated } & $0.0841^{* * *}$ & $0.0287^{* * *}$ & -0.00539 & $0.0183^{*}$ & 0.00491 \\
\hline & $(0.0286)$ & $(0.0110)$ & $(0.0108)$ & $(0.0107)$ & $(0.0135)$ \\
\hline \multirow[t]{2}{*}{ Widowed/widower } & $0.0490^{*}$ & $0.0187^{*}$ & $-0.0165^{*}$ & 0.0110 & 0.00937 \\
\hline & $(0.0258)$ & $(0.00980)$ & $(0.00986)$ & $(0.00960)$ & $(0.0122)$ \\
\hline \multirow[t]{2}{*}{ Primary } & $-0.0820^{* * *}$ & $-0.0425^{* * *}$ & $-0.0136^{* * *}$ & $-0.0398^{* * *}$ & $-0.0411^{* * *}$ \\
\hline & $(0.0135)$ & $(0.00551)$ & $(0.00463)$ & $(0.00548)$ & $(0.00650)$ \\
\hline \multirow[t]{2}{*}{ ZJC } & $-0.195^{* * *}$ & $-0.0957^{* * *}$ & $-0.0403^{* * *}$ & $-0.0847^{* * *}$ & $-0.0894^{* * *}$ \\
\hline & $(0.0154)$ & $(0.00629)$ & $(0.00562)$ & $(0.00619)$ & $(0.00759)$ \\
\hline \multirow[t]{2}{*}{ O' level } & $-0.264^{* * *}$ & $-0.117^{* * *}$ & $-0.0608^{* * *}$ & $-0.104^{* * *}$ & $-0.129^{* * *}$ \\
\hline & $(0.0146)$ & $(0.00593)$ & $(0.00521)$ & $(0.00583)$ & $(0.00723)$ \\
\hline \multirow[t]{2}{*}{$A^{\prime}$ level } & $-0.352^{* * *}$ & $-0.159^{* * *}$ & $-0.0898^{* * *}$ & $-0.134^{* * *}$ & $-0.169^{* * *}$ \\
\hline & $(0.0191)$ & $(0.00799)$ & $(0.00841)$ & $(0.00777)$ & $(0.00989)$ \\
\hline \multirow{2}{*}{$\begin{array}{l}\text { Diploma/certificate after } \\
\text { primary }\end{array}$} & $-0.367^{* * *}$ & $-0.139^{* * *}$ & $-0.0910^{* * *}$ & $-0.119^{* * *}$ & $-0.178^{* * *}$ \\
\hline & $(0.0297)$ & $(0.0107)$ & $(0.0141)$ & $(0.0109)$ & $(0.0160)$ \\
\hline \multirow{2}{*}{$\begin{array}{l}\text { Diploma/certificate after } \\
\text { secondary }\end{array}$} & $-0.371^{* * *}$ & $-0.141^{* * *}$ & $-0.0948^{* * *}$ & $-0.131^{* * *}$ & $-0.199^{* * *}$ \\
\hline & $(0.0213)$ & $(0.00765)$ & $(0.0105)$ & $(0.00753)$ & $(0.0114)$ \\
\hline \multirow[t]{2}{*}{ Graduate/post-graduate } & $-0.324^{* * *}$ & $-0.0900^{* * *}$ & $-0.0530^{* * *}$ & $-0.0879^{* * *}$ & $-0.148^{* * *}$ \\
\hline & $(0.0290)$ & $(0.0103)$ & $(0.0126)$ & $(0.0103)$ & $(0.0150)$ \\
\hline \multirow[t]{2}{*}{ Household size } & $0.0230^{* * *}$ & $0.00196^{* * *}$ & -0.000422 & $0.00137^{* *}$ & $0.00636^{* * *}$ \\
\hline & $(0.00173)$ & $(0.000691)$ & $(0.000672)$ & $(0.000676)$ & $(0.000847)$ \\
\hline \multirow{2}{*}{$\begin{array}{l}\text { Proportion of female } \\
\text { household members }\end{array}$} & -0.0224 & 0.00222 & 0.00243 & $0.0151^{* *}$ & $0.0187^{* *}$ \\
\hline & $(0.0173)$ & $(0.00712)$ & $(0.00708)$ & $(0.00700)$ & $(0.00878)$ \\
\hline \multirow{2}{*}{$\begin{array}{l}\text { Number of mentally ill } \\
\text { household members }\end{array}$} & $0.0217^{*}$ & 0.00184 & 0.00596 & 0.00561 & $0.0110^{*}$ \\
\hline & $(0.0128)$ & $(0.00482)$ & $(0.00438)$ & $(0.00464)$ & $(0.00571)$ \\
\hline \multirow{2}{*}{$\begin{array}{l}\text { Number of chronically ill } \\
\text { household members }\end{array}$} & $0.126^{* * *}$ & $0.0244^{* * *}$ & 0.000663 & $0.0105^{* *}$ & $0.0123^{* *}$ \\
\hline & $(0.0141)$ & $(0.00531)$ & $(0.00470)$ & $(0.00502)$ & $(0.00623)$ \\
\hline \multirow[t]{2}{*}{ Household income [USD] } & $-\overline{0.000225^{* * *}}$ & $-8.88 \mathrm{e}-05^{* * *}$ & $-5.53 e-05^{* * *}$ & $-7.67 e-05^{* * *}$ & $-\overline{0.000146^{* * *}}$ \\
\hline & $(9.42 \mathrm{e}-06)$ & $(3.50 e-06)$ & $(4.31 e-06)$ & $(3.25 e-06)$ & $(5.60 e-06)$ \\
\hline $\begin{array}{l}\text { The household is located in } \\
\text { rural areas [ } 1 \text { if yes] }\end{array}$ & $0.214^{* * *}$ & $0.138^{* * *}$ & $0.0190^{* * *}$ & $0.113^{* * *}$ & $0.316^{* * *}$ \\
\hline
\end{tabular}


Table 5 OLS estimates of the impact of gender on food security (Continued)

\begin{tabular}{llllll}
\hline Variables & $\begin{array}{l}\text { Hunger } \\
\text { score }\end{array}$ & $\begin{array}{l}\text { Poor food } \\
\text { consumption } \\
\text { score } \\
(\mathrm{II})\end{array}$ & $\begin{array}{l}\text { Never } \\
\text { consumes } \\
\text { minerals } \\
(\mathrm{IV})\end{array}$ & $\begin{array}{l}\text { Never } \\
\text { consumes } \\
\text { proteins } \\
(\mathrm{V})\end{array}$ & $\begin{array}{l}\text { Never } \\
\text { consumes } \\
\text { iron } \\
(\mathrm{IV})\end{array}$ \\
\hline \multirow{2}{*}{ Constant } & $(0.0134)$ & $(0.00431)$ & $(0.00373)$ & $(0.00430)$ & $(0.00570)$ \\
& $(0.0133)$ & $(0.00587)$ & $(0.00556)$ & $(0.00568)$ & $(0.00713)$ \\
Observations & $0.882^{* * *}$ & $0.294^{* * *}$ & $0.778^{* * *}$ & $0.244^{* * *}$ & $0.317^{* * *}$ \\
R-squared & $(0.0502)$ & $(0.0152)$ & $(0.0139)$ & $(0.0154)$ & $(0.0208)$ \\
\hline Not & 64,779 & 65,950 & 65,950 & 65,950 & 65,950 \\
\hline
\end{tabular}

Notes: Regression results control for province as well as survey year dummies. Robust standard errors in parentheses $*^{* *}, * *$, and ${ }^{*}$ indicate the 1,5 , and $10 \%$ levels of significance

results are also consistent with previous studies that find that female head households are more prone to food insecurity such as Horrell and Krishnan (2007), King-Dejardin and Owens (2009), Klasen et al. (2015), Peterman et al. (2010), Quisumbing (1996), Quisumbing and McClafferty (2006), and Quisumbing and Pandolfelli (2009) amongst others.

The results in Table 5 also show that education decreases the food insecurity of the household. Indeed, columns I to column V of the table show that as the level of education increases all measures of food insecurity decrease. This finding is consistent with earlier studies such as Garrett and Ruel (1999). Expectedly, columns I to V show that household size, having a chronically or mentally ill household member increase the household food and nutrition insecurity by all proxies.

\section{The impact of gender on the adoption of coping strategies}

Column I of Table 6 shows the impact of gender on the usage of consumption-based coping strategies. According to column I of the table, if the household head is female, the usage of consumption-based coping strategies increases by 0.95 points. This finding therefore confirms Hypothesis 2.1 of this study and affirms the findings of earlier studies such as Cappellini et al. (2014), Günther and Harttgen (2009), and Skoufias and Quisumbing (2005), amongst others. This finding is intuitive since as already noted, the role of food preparation and distribution is usually carried out by females in the Zimbabwean setting. Even if they are the household heads, women are still likely to be involved in the food preparation patterns at home, rather than if the household head is male who is less likely to have a direct role in the preparation of food at home. It therefore follows that females are likely to be more able to change consumption patterns at home without difficulty.

Column II of Table 6 shows the impact of gender on the livelihoods-based coping strategies. The table shows that there is no statistically significant gender differences in the ability to use livelihoods-based coping strategies which is in line with Hypothesis 2.2 of this study. This finding is in line with prior studies such as Günther and Harttgen (2009) and Skoufias and Quisumbing (2005), amongst others, who conclude that female household heads are less likely to be able to engage in long-term measures such as selling a house in the light of hunger than their male counterparts. 
Table 6 OLS estimates of the impact gender on coping strategies

\begin{tabular}{|c|c|c|}
\hline Variables & $\begin{array}{l}\text { Consumption-based coping } \\
\text { strategies index } \\
\text { (l) }\end{array}$ & $\begin{array}{l}\text { Livelihoods-based coping } \\
\text { strategies index } \\
\text { (II) }\end{array}$ \\
\hline \multirow[t]{2}{*}{ Household head is female } & $0.950^{* *}$ & -0.0263 \\
\hline & $(0.379)$ & $(0.0170)$ \\
\hline \multirow[t]{2}{*}{ Age of household head [years] } & $-0.171^{* * *}$ & $-0.00571^{* * *}$ \\
\hline & $(0.00865)$ & $(0.000380)$ \\
\hline \multirow[t]{2}{*}{ Married living together } & $1.984^{* * *}$ & $0.101^{* * *}$ \\
\hline & $(0.738)$ & $(0.0320)$ \\
\hline \multirow[t]{2}{*}{ Married living apart } & $-2.247^{* * *}$ & 0.00648 \\
\hline & $(0.797)$ & $(0.0351)$ \\
\hline \multirow[t]{2}{*}{ Divorced/separated } & $3.380^{* * *}$ & $0.0958^{* *}$ \\
\hline & $(0.885)$ & $(0.0386)$ \\
\hline \multirow[t]{2}{*}{ Widowed/widower } & $3.192^{* * *}$ & $0.145^{* * *}$ \\
\hline & $(0.809)$ & $(0.0347)$ \\
\hline \multirow[t]{2}{*}{ Primary } & $-1.348^{* * *}$ & -0.00715 \\
\hline & $(0.406)$ & $(0.0151)$ \\
\hline \multirow[t]{2}{*}{ ZJC } & $-3.247^{* * *}$ & 0.0157 \\
\hline & $(0.474)$ & $(0.0207)$ \\
\hline \multirow[t]{2}{*}{ O' level } & $-6.372^{* * *}$ & $-0.0473^{* * *}$ \\
\hline & $(0.451)$ & $(0.0182)$ \\
\hline \multirow[t]{2}{*}{$A^{\prime}$ level } & $-9.235^{* * *}$ & -0.0733 \\
\hline & $(0.603)$ & $(0.0450)$ \\
\hline \multirow[t]{2}{*}{ Diploma/certificate after primary } & $-8.230^{* * *}$ & $-0.0901^{*}$ \\
\hline & $(0.970)$ & $(0.0516)$ \\
\hline \multirow[t]{2}{*}{ Diploma/certificate after secondary } & $-10.77^{* * *}$ & $-0.116^{* * *}$ \\
\hline & $(0.617)$ & $(0.0398)$ \\
\hline \multirow[t]{2}{*}{ Graduate/post-graduate } & $-8.761^{* * *}$ & $-0.177^{* * *}$ \\
\hline & $(0.795)$ & $(0.0441)$ \\
\hline \multirow[t]{2}{*}{ Household size } & $1.082^{* * *}$ & $0.0407^{* * *}$ \\
\hline & $(0.0531)$ & $(0.00253)$ \\
\hline \multirow{2}{*}{$\begin{array}{l}\text { Proportion of female household } \\
\text { members }\end{array}$} & -0.0721 & 0.00630 \\
\hline & $(0.537)$ & $(0.0245)$ \\
\hline \multirow{2}{*}{$\begin{array}{l}\text { Number of mentally ill household } \\
\text { members }\end{array}$} & $0.762^{*}$ & -0.0135 \\
\hline & $(0.401)$ & $(0.0156)$ \\
\hline \multirow{2}{*}{$\begin{array}{l}\text { Number of chronically ill household } \\
\text { members }\end{array}$} & $3.468^{* * *}$ & $0.106^{* * *}$ \\
\hline & $(0.460)$ & $(0.0184)$ \\
\hline \multirow[t]{2}{*}{ Household income [USD] } & $-0.00885^{* * *}$ & $-0.000185^{* * *}$ \\
\hline & $(0.000332)$ & $(1.32 \mathrm{e}-05)$ \\
\hline \multirow{2}{*}{$\begin{array}{l}\text { The household is located in rural areas } \\
\text { [1 if yes] }\end{array}$} & $11.49^{* * *}$ & $0.262^{* * *}$ \\
\hline & $(0.378)$ & $(0.0180)$ \\
\hline \multirow[t]{2}{*}{ Constant } & $26.39^{* * *}$ & -0.0686 \\
\hline & $(1.444)$ & $(0.0588)$ \\
\hline
\end{tabular}


Table 6 OLS estimates of the impact gender on coping strategies (Continued)

\begin{tabular}{lll}
\hline & $\begin{array}{l}\text { Consumption-based coping } \\
\text { strategies index }\end{array}$ & $\begin{array}{l}\text { Livelihoods-based coping } \\
\text { strategies index } \\
\text { Variables }\end{array}$ \\
\hline Observations & $(\mathrm{II})$ \\
R-squared & 65,950 & 45,663 \\
\hline
\end{tabular}

Notes: Regression results control for province as well as survey year dummies. Robust standard errors in parentheses $* * * * *$, and ${ }^{*}$ indicate the 1,5 , and $10 \%$ levels of significance

Gender heterogeneity in the usage of coping strategies when confronted by food and nutrition insecurity

Panel A of Table 7 shows the gender heterogeneity in the household usage of consumption-based coping strategies when confronted by food and nutrition insecurity. According to columns I to $\mathrm{V}$ of panel A, there is positive and statistically significant correlation in the usage of consumption-based coping strategies and household food and nutrition insecurity. Households that are food insecure are more likely to engage in consumption-based coping strategies. In terms of gender heterogeneity in the usage of consumption strategies in the presence of food insecurity, it is only observed in column IV of panel A where female household heads are more likely to use consumption-based coping strategies in the presence of lacking proteins but not in any other measure of household food and nutrition insecurity.

Panel B of Table 7 shows the gender heterogeneity in the usage of livelihoods-based coping strategies in the presence of household food and nutrition insecurity. According to columns I to $\mathrm{V}$ of panel $\mathrm{A}$, there is positive and statistically significant correlation in the usage of livelihoods-based coping strategies and household food and nutrition

Table 7 OLS estimates of gender heterogeneity in the usage of coping strategies when confronted with food and nutrition insecurity

\begin{tabular}{|c|c|c|c|c|c|}
\hline \multirow[t]{2}{*}{ Variables } & $\begin{array}{l}\text { Hunger } \\
\text { score }\end{array}$ & $\begin{array}{l}\text { Poor food } \\
\text { consumption } \\
\text { score }\end{array}$ & $\begin{array}{l}\text { Never } \\
\text { consumes } \\
\text { minerals }\end{array}$ & $\begin{array}{l}\text { Never } \\
\text { consumes } \\
\text { proteins }\end{array}$ & $\begin{array}{l}\text { Never } \\
\text { consumes } \\
\text { iron }\end{array}$ \\
\hline & $(\mathrm{l})$ & (II) & (IV) & $(\mathrm{V})$ & (IV) \\
\hline \multicolumn{6}{|l|}{ Panel A } \\
\hline \multirow{2}{*}{$\begin{array}{l}\text { Household head is female } \times \\
\text { Consumption-based coping strategy } \\
\text { index }\end{array}$} & - & $7.69 \mathrm{e}-05$ & $8.64 \mathrm{e}-05$ & $0.000337^{* * *}$ & -0.000197 \\
\hline & $(0.000338)$ & $(0.000128)$ & $(0.000134)$ & $(0.000124)$ & $(0.000137)$ \\
\hline \multirow[t]{2}{*}{ Household head is female } & $0.0353^{* * *}$ & $0.0254^{* * *}$ & $0.00988^{* *}$ & $0.0326^{* * *}$ & $0.0664^{* * *}$ \\
\hline & $(0.00726)$ & $(0.00344)$ & $(0.00462)$ & $(0.00347)$ & $(0.00473)$ \\
\hline \multirow{2}{*}{$\begin{array}{l}\text { Consumption-based coping strategy } \\
\text { index }\end{array}$} & $0.0149^{* * *}$ & $0.00355^{* * *}$ & $0.00195^{* * *}$ & $0.00262^{* * *}$ & $0.00405^{* * *}$ \\
\hline & $(0.000203)$ & $(7.83 e-05)$ & $(8.25 e-05)$ & $(7.40 e-05)$ & $(8.63 e-05)$ \\
\hline \multicolumn{6}{|l|}{ Panel B } \\
\hline \multirow[t]{2}{*}{$\begin{array}{l}\text { Household head is female } \times \text { Livelihoods- } \\
\text { based coping strategy index }\end{array}$} & $0.0329^{* * *}$ & $-0.0110^{* * *}$ & 0.000742 & -0.00511 & $-0.0164^{* * *}$ \\
\hline & $(0.0114)$ & $(0.00374)$ & $(0.00390)$ & $(0.00356)$ & $(0.00436)$ \\
\hline \multirow[t]{2}{*}{ Household head is female } & $0.0763^{* * *}$ & $0.0379 * * *$ & $0.0186^{* * *}$ & $0.0458^{* * *}$ & $0.0741^{* * * *}$ \\
\hline & $(0.00966)$ & $(0.00399)$ & $(0.00431)$ & $(0.00401)$ & $(0.00531)$ \\
\hline \multirow[t]{2}{*}{ Livelihoods-based coping strategy index } & $0.222^{* * *}$ & $0.0344^{* * *}$ & $0.0260^{* * *}$ & $0.0211^{* * *}$ & $0.0312^{* * *}$ \\
\hline & $(0.00635)$ & $(0.00212)$ & $(0.00216)$ & $(0.00195)$ & $(0.00247)$ \\
\hline
\end{tabular}

Notes: Regression results control for province as well as survey year dummies. Robust standard errors in parentheses $*^{* *}, *^{*}$, and ${ }^{*}$ indicate the 1,5 , and $10 \%$ levels of significance 
insecurity. According to columns I to $\mathrm{V}$ of panel B, there is statistically significant negative correlation in the usage of livelihoods-based coping strategies and being female in the presence of household food and nutrition insecurity. Indeed, column I shows that being female reduces the propensity to use household livelihoods-based coping strategies as the household hunger score increases. The pattern in column I is observed in column II to IV of panel B of Table 7. These findings therefore strongly corroborate Hypothesis 3.2 of this study. Furthermore, the findings presented in panel B of the Table 7 also affirm the earlier findings of studies such as Günther and Harttgen (2009) and Skoufias and Quisumbing (2005), amongst others, who find that females are less able to use livelihoods-based coping strategies in the presence of household food and nutrition insecurity.

\section{Conclusion and policy recommendations}

On the basis of a large-scale nationally representative household data from four pooled cross-section surveys conducted by ZimVAC from 2013 to 2017 comprising 67,857 households in Zimbabwe, this study assessed the existence of gender heterogeneity in the vulnerability to food insecurity, usage of coping strategies, and the household usage of such coping strategies when confronted by food and nutrition insecurity.

The study offers three major findings. Firstly, consistent with prior studies, the study finds that female-headed households are more prone to food insecurity than those that are male-headed. The study finds that female-headed households are ceteris paribus, more likely to have higher household hunger scores, poor food consumption scores as well as likely to go without consuming vitamins, minerals or foods rich in iron.

Secondly, the study finds that female-headed households are more likely to be able to use consumption-based coping strategies but not livelihoods-based coping strategies more than their male counterparts. This finding is intuitive given that consumptionbased coping strategies are short-term and are more likely to be within the realm of decisions that are preserved for women specifically the preparation and distribution of food within the traditional household in the Zimbabwean setting. Women however even though they might be household heads might be encumbered by societal conventions in engaging in more long-term livelihoods-based coping strategies than their male counterparts. In that regards, the study therefore finds no statistically significant gender heterogeneity in the usage of livelihoods-based coping strategies.

Finally, the study finds that there is little evidence in the gender heterogeneity in the household usage of consumption-based coping strategies when confronted by food and nutrition insecurity. The little evidence of gender heterogeneity in the usage of consumption-based coping strategies is likely to be because even in the households where they are headed by males the implementation of consumption-based coping strategies is still done by women in the household. On the other hand, when one looks at the longerterm livelihoods-based coping strategies, female-headed households are less likely to employ livelihoods-based coping strategies when confronted by food and nutrition insecurity than their male counterparts. Their lesser ability is likely to stem from the socio-cultural constraints that they are likely to encounter in the implementation of livelihoods-based coping strategies when confronted by food and nutrition insecurity.

In summary, whilst female-headed households are more prone to food insecurity than male-headed households, they are more encumbered in the use of long-term coping strategies than their male counterparts. 


\section{Appendix}

Table 8 Measurement of consumption coping strategy index

\begin{tabular}{ll}
\hline $\begin{array}{l}\text { During the last } 7 \text { days, were there days (and, if so, how many) when your } \\
\text { household had to employ one of the following strategies (to cope with a }\end{array}$ & $\begin{array}{l}\text { Frequency (number of } \\
\text { dack from 0 to 7) }\end{array}$ \\
lack food or money to buy it)? & 1 \\
\hline Relied on less preferred, less expensive food & 1 \\
Borrowed food or relied on help from friends or relatives & 1 \\
Reduced the number of meals eaten per day & 2 \\
Reduced portion size of meals & 3 \\
$\begin{array}{l}\text { Reduction in the quantities consumed by adults/mothers for young } \\
\text { children }\end{array}$ & \\
\hline
\end{tabular}

Table 9 Measurement of livelihoods based coping strategies index

\begin{tabular}{lc}
\hline During the past 30 days, did anyone in your household have to engage in any of the following & Weight \\
activities because there was not enough food or money to buy food? & 2 \\
\hline Sold household assets/goods (radio, furniture, refrigerator, television, jewellery, clothes, etc.) & 2 \\
Purchased food on credit or borrowed food & 0 \\
Spent savings & 2 \\
Borrowed money & 3 \\
Sold productive assets or means of transport (sewing machine, wheelbarrow, bicycle, car, etc.) & 0 \\
Consumed seed stocks that were to be held/saved for the next season & 0 \\
Withdrew children from school & 0 \\
Sold house or land & 0 \\
Begged & 0
\end{tabular}

\section{Abbreviations}

ZimVAC: Zimbabwe Vulnerability Assessment Committee

\section{Acknowledgements}

We also acknowledge enumerators, sample respondents, and all the ZimVAC members for providing the data sets used for this study.

\section{Authors' contribution}

Both authors contributed equally to this manuscript. Both authors read and approved the final manuscript.

\section{Funding}

No funding was available for this research.

\section{Availability of data and materials}

The data that support the findings of this study can be obtained from the authors based on request.

\section{Ethics approval and consent to participate}

Ethical approval and consent to participate is not applicable for our study.

\section{Competing interests}

The authors declare that they have no competing interests.

\section{Author details}

${ }^{1}$ Department of Economics, Bindura University of Science Education, P. Bag, 1020 Bindura, Zimbabwe. ${ }^{2}$ Food and Nutrition Council of Zimbabwe, 1574 Alpes Road, Hatcliffe, Harare, Zimbabwe. 
Received: 10 April 2018 Accepted: 18 November 2019

Published online: 28 December 2019

\section{References}

Christian P (2010) Impact of the economic crisis and increase in food prices on child mortality: exploring nutritional pathways. Journal of Nutrition 140:177-181

Christiaensen LM, Boisvert RN (2000) "On Measuring Household Food Vulnerability: Case Evidence from Northern Mali," Working Papers 127676, Cornell University, Department of Applied Economics and Management

Coates J, Frongillo EA, Swindale A, Rogers BL, Webb P, Bilinsky P (eds) (2006) "Advances in Developing Country Food Insecurity Measurement". Journal of Nutrition Suppl 135 (5S)

Croson R, Gneezy U (2009) Gender differences in preferences. Journal of Economic Literature 47(2):448-474

Dercon S, Krishnan P (1999) In sickness and in health: risk-sharing within households in Ethiopia. Journal of Political Economy 108(4):688-727

Fafchamps M, Udry C, Czukas K (1998) Drought and saving in West Africa: are livestock a buffer stock? Journal of Development Economics 55(2):273-305

FAO (2008) The state of food insecurity in the world. High food prices and food security - threats and opportunities. Rome: FAO. ftp://ftp.fao.org/docrep/fao/011/i0291e/i0291e00a.pdf

FAO (2010) The state of food insecurity in the world: addressing food insecurity in protracting crises. Alinovi, L., L. Russo and D. Maxwell (eds). Food and Agriculture Organization of the United Nations.

FAO (2011) The state of food and agriculture: women in agriculture- closing the gender gap for development. FAO, Rome

Fletschner D, Anderson L-C, Cullen A (2010) Are women as likely to take risks and compete? Behavioural findings from Central Vietnam. Journal of Development Studies 46(8):1459-1479

Fletschner D, Carter M (2008) Constructing and reconstructing gender: reference group effects and women's demand for entrepreneurial capital. Journal of SocioEconomics 37(2):672-693

Garrett J, Ruel M (1999) Are Determinants of Rural and Urban Food Security and Nutritional Status Different? Some Insights from Mozambique, World Development 27(11):1955-1975

Gneezy U, Rustichini A (2004) Gender and competition at a young age. American Economic Review 94(2):377-381

Günther I, Harttgen K (2009) "Estimating Households Vulnerability to Idiosyncratic and Covariate Shocks: A Novel Method Applied in Madagascar," World Development. Elsevier 37(7):1222-1234

Gupta P, Singh K, Seth V, Agarwal S, Mathur P (2015) Coping strategies adopted by households to prevent food insecurity in urban slums of Delhi, India. Journal of Food Security 3:6-10

Horrell S, Krishnan P (2007) Poverty and productivity in female-headed households in Zimbabwe. Journal of Development Studies 43(8):1351-1380

Ivanic M, Will M (2008) Implications of higher global food prices for poverty in low-income countries-super-1. Agricultural Economics, International Association of Agricultural Economists 39(s1):405-416

Ivanic M, Will M, Zaman H (2012) Estimating the short-run poverty impacts of the 2010-11 surge in food prices. World Development 40(11):2302-2317

Kairiza T, Kiprono P, Magadzire V (2017) Gender differences in financial inclusion amongst entrepreneurs in Zimbabwe. Small Business Economics 48(1):259-272

King-Dejardin A, Owens J (2009) Asia in the global economic crisis: Impacts and responses from a gender perspective. ILO Regional Office for Asia and the Pacific, Bangkok

Klasen S, Lechtenfeld T, Povel F (2015) A feminization of vulnerability? Female headship, poverty, and vulnerability in Thailand and Vietnam. World Development 71(C):36-53

Maxwell D, Caldwell R (2008) The coping strategies index field methods manual. Second Edition. Cooperative Assistance for Relief Everywhere (CARE). Atlanta, GA: CARE

Maxwell D, Ahiadeke C, Levin C, Armar-Klemesu M, Zakariah S, Lamptey GM (1999) Alternative food-security indicators: Revisiting the frequency and severity of coping strategies. Food Policy. https://doi.org/10.1016/S0306-9192(99)00051-2

Peterman A, Behrman J, Quisumbing A (2010) A review of empirical evidence on gender differences in non-land agricultural inputs, technology, and services in developing countries. Washington, D.C. IFPRI

Powell M, Ansic D (1997) Gender differences in risk behaviour in financial decision-making: an experimental analysis. Journal of Economic Psychology 18(6):605-628

Quisumbing A (1996) Male-female differences in agricultural productivity: methodological issues and empirical evidence. World Development 24(10):1579-1595

Quisumbing A, McClafferty B (2006) Using gender research in development. Food Security in Practice Technical Guide Series 2. Washington, D.C.: IFPRI.

Quisumbing A, Meinzen-Dick R, Bassett L (2008) Helping women respond to the global food price crisis. Policy Brief 7 . Washington, DC: IFRPI.

Quisumbing A, Pandolfelli L (2009) Promising approaches to address the needs of poor female farmers: Resources, constraints, and interventions. World Development 38(4):581-592. https://doi.org/10.1016/j.worlddev.2009.10.006

Reevy G, Maslach C (2001) People's use of social support: gender and personality differences. Sex Roles 44:437-459

Skoufias E, Quisumbing A (2005) Eur J Dev Res 17:24. https://doi.org/10.1080/09578810500066498

Tirado M, Clarke R, Jaykus L-A, McQuatters-Gollop A, Frank J (2010) Climate change and food safety: a review. Food Research International 43:1745-1765

\section{Publisher's Note}

Springer Nature remains neutral with regard to jurisdictional claims in published maps and institutional affiliations. 